


\title{
Contagious Bovine Pleuropneumonia: Sero-preva- lence and associated risk factors in Gudeya Bila and Boneya Boshe Districts of East Wollega Zone, Oro- mia, Ethiopia
}

Tolesa Neggasa ${ }^{1,2}$, Feyissa Begna ${ }^{2}$, Moti Wakgari ${ }^{3}$, Sisay Shibashi ${ }^{3}$,Eshetu Gezahegn ${ }^{3}$, Fikadu Bekele ${ }^{3}$, TadeleTolosa ${ }^{2^{*}}$

${ }^{1}$ West Wollega zone livestock and fishery resources development, Nejo district livestock and fishery resources development office, Nejo.

${ }^{2}$ Jimma University, College and Veterinary Medicine, School of Veterinary, P. O. Box 307, Jimma,

${ }^{3}$ Bedele Regional Veterinary Laboratory, P. O. Box 15, Bedele, Ethiopia

\begin{abstract}
Contagious bovine pleuropneumonia (CBPP) remains a huge threat to cattle production in sub Saharan African countries in general and in Ethiopia in particular. A cross sectional study was conducted between November, 2017 and June, 2018 to estimate the seroprevalence and associated risk factors of CBPP in the Gudeya Bila and Boneya Boshe districts of East Wollega Zone, Oromia Regional State. The study was conducted on 384 cattle with no history of vaccination against CBPP, using systematic random sampling technique. Blood samples were collected from the jugular vein of each animal and tested by competitive ELISA. Information on risk factors influencing the occurrence of CBPP was collected using questionnaire survey. Data obtained from both serological and questionnaire surveys were analyzed by using SPSS software version 20. Logistic regression was used to analyze the association of exposure variables with anti-mycoplasma mycoides subspecies small colony antibodies. The results indicated that, the overall seroprevalence of CBPP at individual animal-level and herd-level was $8.6 \%$ and $26.3 \%$, respectively. There was a statistically significant association in the sero-prevalence of Mycoplasma mycoides subsp. mycoides SC $(\mathrm{MMmsSC})$ antibody $(\mathrm{P}<0.05)$ with the poor body condition score, origin of animals (purchasing from outside of herd) and previous history of CBPP disease at individual animal and large herd size at herd level. This study showed that the overall prevalence of CBPP in study area was high. This warrants the implementation of appropriate preventive and control practice.
\end{abstract}

Keywords: Boneya Boshe, Bovine, CBPP, c-ELISA, Ethiopia, Gudeya Bila, Sero-prevalence 


\section{Introduction}

Agriculture is the backbone of Ethiopian economy. Livestock is very notable in their contribution to agriculture. They contribute $13-16 \%$ of the total gross domestic product (GDP), 30- 35\% of agricultural gross domestic product (GDP) and more than $85 \%$ of farm cash income (Tsedeke and Endrias, 2011; Abera et al., 2016). Despite the fact that this magnificent figure is achieved from livestock sector and making the gap of economy very narrow thereby alleviating food insecurity, diseases of animals like contagious bovine pleuropneumonia (CBPP) is playing a principal role for not to achieve the real asset expected from this sector (Lesnoff et al., 2004; Adugna, 2017). Contagious bovine pleuropneumonia is a highly infectious acute, sub-acute and chronic disease of cattle caused by Mycoplasma mycoides subspecies mycoides small colony (MmmSC). It is one of the diseases recognized by OIE that needs to be controlled or eradicated through a national surveillance protocol (John, 2016; Dereje and Shawul, 2017).

Although CBPP was worldwide in its distribution, it was eradicated from most continents, by the mid- $20^{\text {th }}$ century. However, because of the economic and financial difficulties that affected the ability of governments to adequately fund veterinary services, the disease is still widely distributed in sub-Saharan African countries. Contagious bovine pleuropneumonia directly impacts economies through cattle mortality and morbidity (Dereje and Shawul, 2017) and also by being a barrier to trade and reduces the value of livestock and the income of value chain stakeholders in many African countries (Tambi et al., 2006; Joerg, 2014). In recent years, CBPP has been reported from countries like Botswana, where it was previously eradicated (Alemayehu et al., 2015). Contagious bovine pleuropneumonia is one of the major diseases in Ethiopia that hampering export of livestock and livestock products to the international markets since long time (Farmer, 2010). Among the exacerbating risk factors of contagious bovine pleuropneumonia in Ethiopia are; lack of knowledge of the disease by farmers, vaccine shortage, poor diagnostic assays, management system, limitation of epidemiological information about the disease, concentration of livestock at watering points and grazing area and difficulty to control of cattle movements are the principal things which have been cited by many literatures (Ebisa et al., 2015).

In western Oromia farming communities there are different animal diseases in which their etiological agent was not identified and affecting production and 
productivity of livestock and threatening the livelihood of small scale farmers. East Wollega zone is one of west Oromia zone in which previously study based on food security was conducted and reported that feed shortage and massive cattle death was a main problem of the zone. The disease that caused massive cattle death at reporting time was tentatively diagnosed as pasteurellosis and it might be other respiratory disease like CBPP (Mersha, 2016). However, there was no systematic study conducted to investigate the status of this disease in the area, insufficient epidemiological information and limited resources to apply control measures; thus study was planned to determine seroprevalence and its associated risk factors CBPP in Boneya Boshe and Gudeya Bila districts.

\section{Materials and methods}

\section{Description of the study area}

The study was conducted in Gudeya Bila and Boneya Boshe districts of East Wollega zone. Gudeya Bila district is found in the East Wollega zone of Oromia Regional State, Western Ethiopia which is located at $274 \mathrm{~km}$ West of Addis Ababa, at $09^{\circ} 17^{\prime} 363^{\prime \prime} \mathrm{N}$ latitude and $037^{\circ} 01^{\prime} 460^{\prime \prime} \mathrm{E}$ longitudes with an altitude ranging from 1876 -2092 meters above sea level. The area is characterized by humid tropical climate with annual rainfall that ranges from 1000-2200 millimeter per annum with average temperature of $20^{\circ} \mathrm{C}$ (CSA, 2017). The district has 121, 081 cattle population (GBLFRDO, 2017). The district has fifteen Peasant associations (PAs). Boneya Boshe district is found in the East Wollega zone of Oromia State, Western Ethiopia which is located at $307 \mathrm{~km}$ West of Addis Ababa, at $08^{\circ} 54^{\prime} 045^{\prime \prime} \mathrm{N}$ latitude and $037^{\circ} 00^{\prime} 136^{\prime \prime} \mathrm{E}$ longitudes with an altitude ranging from 1613-1641 meters above sea level. The area is characterized by a humid tropical climate with annual rainfall that ranges from 1000-1200 millimeter per annum with average temperature of $20.9^{\circ} \mathrm{C}$ (CSA, 2017). The district has cattle population of 102, 917 (BBLFRDO, 2017). The district has ten PA's (Figure 1). 


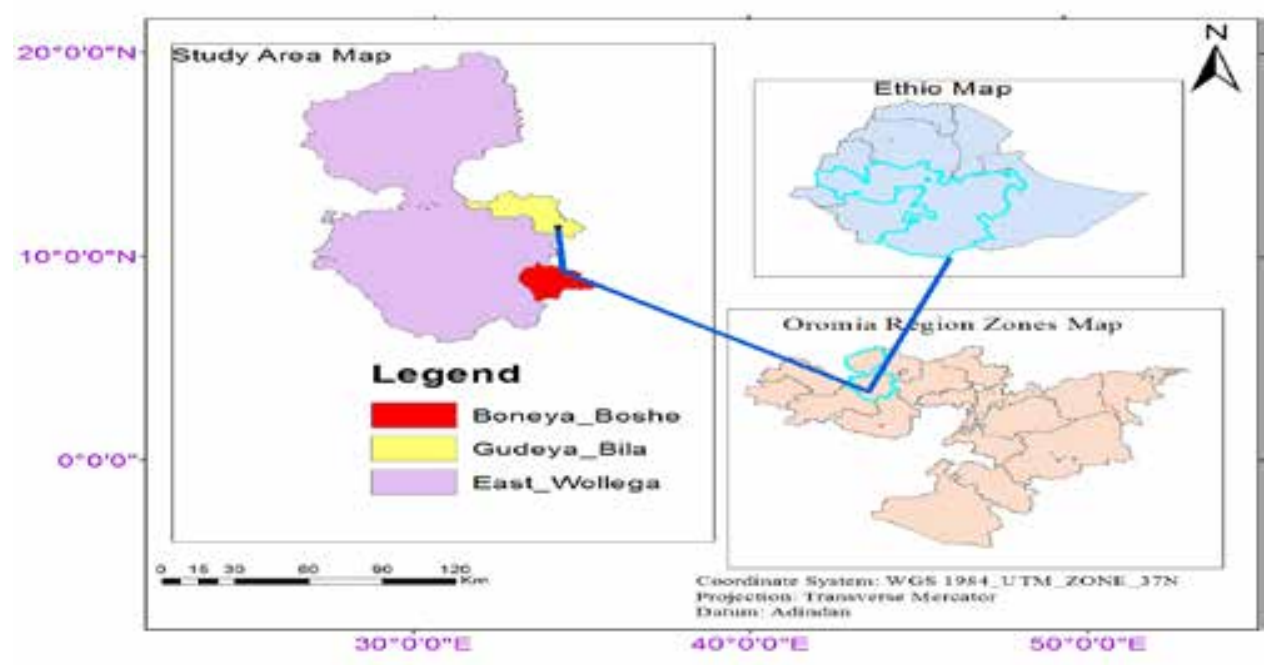

Figure 1: Study area map (CSA, 2017)

\section{Study Design}

A cross-sectional study was conducted using a systematic random sampling technique to select the study cattle. The size of the households' and list of herd distribution were identified from PAs and then both blood sample collection and questionnaire survey were conducted. Pre-tested semi-structured questionnaire was used to collect information on factors influencing the occurrence of CBPP within or between herds by face-to face interview. Data on sex, age, origin of animal, herd size, previous infection history, body condition scores of animal, animal management, introduction of new animal, herd contact and herd contact area were recorded. The body condition scores of animals were scored according to DEFRA (2001).

\section{Target and study population}

The target populations in this study were all local Horo breed cattle above six months of age of both sexes with no history of vaccination in selected PAs of Gudeya Bila and Boneya Boshe districts of Oromia Regional State and the study populations in this study were all cattle selected for purpose of this study. 


\section{Sampling strategy}

Four PAs form Boneya Boshe and 4 PAs from Gudeya Bila district were selected based on cattle population and access to road facility and individual animals were selected by using systematic random sampling technique.

\section{Sample size determination}

The sample size was determined using the formula described by Thrusfield (2007) by considering an expected prevalence of 50\% with an absolute precision of $5 \%$ with $95 \%$ confidence level.

$$
\mathrm{N}=\underline{1.96}{ }^{2} \underline{\mathrm{X} \operatorname{Pexp}(1-\mathrm{Pexp})} \mathrm{d}^{2}
$$

Where $\mathrm{N}=$ sample size of the study population

$\mathrm{d}=$ Absolute desired precision

$\mathrm{p}=$ expected prevalence in the study area

$\mathrm{N}=\underline{1.96} \underline{\underline{\mathrm{X}} 0.5(1-0.5)}=384$

$0.05^{2}$

Therefore 384 cattle were selected from both districts (186 cattle from Boneya Boshe and 198 cattle Gudeya Bila) using proportional allocation based on the cattle population in each district.

\section{Questionnaire survey}

Ninety-five households were interviewed during sampling of study cattle. The questionnaire was covering information on the name of the owner, location, sex, age, origin of animal, herd size, previous infection history of contagious bovine pleuropneumonia, animal management, contact of herds with one or more animals or herds at grazing areas or watering points, introduction of new animals. This questionnaire was administered by face-to-face interview with the owner of animals using the local language (Afaan Oromo). 


\section{Sample collection and Laboratory test (Competitive ELISA (c- ELI- SA))}

About 10 milliliters of blood samples were collected from the jugular vein of each cattle using sterile vacutainer tubes and needles by following aseptic procedure after cattle restrained by owner and each sample was properly labeled (include all necessary information like owner name, species of animal, sex, age, breed, body condition etc.). The samples were kept protected from sun light in a slanting position for 6-8 hours. The serum was separated manually and transfered to a sterile tube and stored at $-20^{\circ} \mathrm{C}$ and analysis with Competitive ELISA at Bedele Veterinary Regional Laboratory. The serum samples were tested by competitive enzyme-linked immunosorbent assay (c-ELISA) to detect MmmSC antibodies based on the manufacturer instruction. Competitive ELISA is an OIE prescribed test and can be used for official CBPP testing (OIE, 2014).

\section{Data analysis}

Data obtained from both serological tests and questionnaire surveys were entered and stored in Microsoft (MS) Excel spreadsheet program and analyzed using SPSS software programs version 20. The total seroprevalence of individual animals was calculated by dividing the number of c-ELISA positive animals by the total number of animals tested and herd prevalence was calculated by number of herd positive to total number of herds tested. A herd was considered seropositive, if at least one animal in the herd was found seropositive. Individual animal risk factors like age, sex, body condition scores, history of disease and origin of animal and herd level risk factors like herd size, management, herd contact with other herds, contact area and introduction of new animal were analyzed.

Univariable logistic regression was used to select the exposure variables forward for multivariable analysis. Factors were selected for final multivariable logistic regression analysis if the p-value was $\leq 0.25$ (sex, age, body condition, disease history and origin at individual animal level and large herd size and management at herd level). The strength of association between the risk factors and the occurrence of the disease was assessed using Odds Ratio (OR). Pearson correlation coefficients were used to check the variables for co-linearity. Then, multivariable analysis was conducted and non-significant variables were removed sequentially using backward elimination at $\mathrm{p}<0.05$. 


\section{Results}

\section{Prevalence}

From the total animals of 384 examined 33 of them were found to be positive for anti-MmmSC antibody. The overall sero-prevalence of CBPP at individual animal-level was $8.6 \%(\mathrm{n}=33 / 384)(95 \%$ CI: $5.8 \%-11.4 \%)$. From the total of 95 herds examined 25 of them were found to be positive to CBPP antibodies with an estimated seroprevalence of CBPP at herd-level 26.3\% (n=25/95) $(95 \%$ CI: $17.5 \%-35.2 \%)$. The positive animal for MmmSC antibodies in the Boneya Boshe and Gudeya Bila were 10.8\% (20/186) and 6.6\% (13/198), respectively (Table 1).

Table 1: Sero-prevalence of contagious bovine pleuropneumonia in study area

\begin{tabular}{llcccc}
\hline Factor & Categories & $\begin{array}{l}\text { No of } \\
\text { examined }\end{array}$ & $\begin{array}{l}\text { Prevalence } \\
\text { (\%) }\end{array}$ & 95\%CI & \\
& Gudeyabila & 198 & $13(6.6)$ & 3.1 & Lower \\
\hline Districts & Boneyaboshe & 186 & $20(10.8)$ & 6.3 & 15.0 \\
Gudeyabila & Harogudisa & 50 & $1(2.0)$ & 1.9 & 5.9 \\
& Henajawaja & 52 & $5(9.6)$ & 1.6 & 17.6 \\
& Jare & 48 & $4(8.3)$ & 0.5 & 16.1 \\
& Agalogidami & 48 & $3(6.3)$ & 0.6 & 13.1 \\
Boneyaboshe & Ejersagute & 51 & $12(23.5)$ & 11.9 & 35.2 \\
& Gala gore & 43 & $5(11.6)$ & 2.1 & 21.2 \\
& Bilo & 45 & $2(4.4)$ & 1.6 & 10.5 \\
& Jawis & 47 & $1(2.1)$ & 2.0 & 6.3 \\
\hline
\end{tabular}

\section{Risk factors}

Animal- level risk factors

Male animals have high sero-prevalence $11.3 \%$ (17/151) than female $6.9 \%$ (16/233). Prevalence of CBPP in animals with age $>5$ years $10.6 \%(19 / 180)$ were higher than animals with age $\leq 5$ years $6.9 \%$ (14/204). Animal with poor body condition score $12.1 \%$ (28/ 231) has high sero-prevalence than animal with good body condition score 3.3\% (5/153) and significantly associated $(p<0.05)$ with anti-MmmSC antibodies. Prevalence of disease among animal 
with history of disease $13.3 \%$ (23/173) were higher than cattle with no disease history $4.5 \%(10 / 211)$ and statistically associated $(\mathrm{p}<0.05)$ ant-MmmSC antibodies. Animal replacement from outside the herd was statistically associated with anti-MmmSC antibody where the herds with animals replaced was found to be higher $17.1 \%(9 / 52)$ sero prevalent than animal with own source origin $7.2 \%(24 / 332)$ (Table 2 and 3$)$.

Table 2: Sero-prevalence of CBPP antibody with potential risk factors

\begin{tabular}{|c|c|c|c|c|c|c|c|}
\hline Factor & Categories & & $\begin{array}{l}\text { No of } \\
\text { exami } \\
\text { ned }\end{array}$ & $\begin{array}{l}\text { Preval } \\
\text { ence (\%) }\end{array}$ & $\begin{array}{l}\mathbf{9 5 \%} \text { CI } \\
\text { Crude } \\
\text { OR } \\
(95 \% \\
\text { CI) }\end{array}$ & $\begin{array}{l}\text { Univar } \\
\text { iable anal } \\
\text { ysis } \\
\text { p-value }\end{array}$ & \\
\hline \multirow{9}{*}{$\begin{array}{l}\text { Individual } \\
\text { animal level }\end{array}$} & Sex & Male & 151 & $17(11.3)$ & $6.2-16.3$ & $0.4(0.2-1.0)$ & 0.06 \\
\hline & & Female & 233 & $16(6.9)$ & $3.6-10.1$ & & \\
\hline & Age & $\leq$ 5years & 204 & $14(6.9)$ & $3.4-10.3$ & $1.7(0.7-4.1)$ & 0.20 \\
\hline & & $>5$ years & 180 & $19(10.6)$ & $6.0-15.0$ & & \\
\hline & BCS & Poor & 231 & $28(12.1)$ & 7.9-16.3 & $5(1.6-15.8)$ & 0.09 \\
\hline & & Good & 153 & $5(3.3)$ & $0.5-6.1$ & & \\
\hline & Disease history & Yes & 173 & $23(13.3)$ & $8.2-18.3$ & $5.6(2.0-15.9)$ & 0.001 \\
\hline & & No & 211 & $10(4.5)$ & $1.9-7.6 .0$ & & \\
\hline & Origin & $\begin{array}{l}\text { Own source } \\
\text { Outside }\end{array}$ & $\begin{array}{c}332 \\
52\end{array}$ & $\begin{array}{l}24(7.2) \\
9(17.1)\end{array}$ & $\begin{array}{l}4.4-10.0 \\
7.0-27.6\end{array}$ & $\begin{array}{c}12.4(3.0- \\
51.9)\end{array}$ & 0.001 \\
\hline \multirow[t]{10}{*}{ Herd level } & Herd size & $\begin{array}{l}\leq 36 \text { herd } \\
\text { size }\end{array}$ & 64 & $12(18.8)$ & 9.2 & 28.3 & \\
\hline & & $\begin{array}{l}>36 \text { herd } \\
\text { size }\end{array}$ & 31 & 13(41.9) & 24.6 & 59.3 & 0.02 \\
\hline & Management & Extensive & 67 & $19(28.4)$ & 17.6 & 39.2 & 0.2 \\
\hline & & $\begin{array}{l}\text { Semi } \\
\text { extensive }\end{array}$ & 28 & $6(21.4)$ & 6.2 & 36.6 & \\
\hline & Herd contact & Yes & 92 & $24(26.1)$ & 17.1 & 35.1 & 0.60 \\
\hline & $\begin{array}{l}\text { animal introduc- } \\
\text { tion }\end{array}$ & No & 3 & 1(33.3) & 20.0 & 86.7 & \\
\hline & $\begin{array}{l}\text { Animal } \\
\text { introduction }\end{array}$ & $\begin{array}{l}\text { Yes } \\
\text { No }\end{array}$ & $\begin{array}{l}46 \\
49\end{array}$ & $\begin{array}{l}10(21.7) \\
15(30.6)\end{array}$ & $\begin{array}{c}9.8 \\
17.7\end{array}$ & $\begin{array}{l}33.7 \\
43.5\end{array}$ & 0.90 \\
\hline & Contact area & Watering & 28 & $9(32.1)$ & 14.8 & 49.4 & 0.90 \\
\hline & & $\begin{array}{l}\text { Water \& } \\
\text { grazing }\end{array}$ & 61 & 15 & 13.8 & & \\
\hline & & & 3 & 1 & 20 & & \\
\hline
\end{tabular}


Table 3: Results of multivariable analysis of potential risk factors

\begin{tabular}{llcccc}
\hline Factors & Categories & $\begin{array}{l}\text { No of } \\
\text { examined }\end{array}$ & Prevalence (\%) & $\begin{array}{l}\text { Multivariable } \\
\text { analysis }\end{array}$ & \\
\cline { 4 - 6 } & & & $\begin{array}{l}\text { Adjusted } \\
\text { OR(95\% CI) }\end{array}$ & P-value \\
\hline Bcs & Poor & 231 & $28(12.1)$ & $4.6(1.6-13.2)$ & 0.01 \\
& Good & 153 & $5(3.3)$ & $*$ & \\
Disease & Yes & 173 & $23(13.3)$ & $4.9(1.9-12.9)$ & 0.01 \\
history & No & 211 & $10(4.7)$ & $*$ & \\
Origin & Outside & 52 & $9(17.3)$ & $12.5(3.1-51.0)$ & 0.01 \\
& Own herd & 332 & $24(7.2)$ & $*$ & \\
*= reference & & & & &
\end{tabular}

Herd level risk factors

Among the potential risk factors assessed at herd level prevalence of CBPP was higher in large herd size $41.9 \%(13 / 31)$ than lower herd size $18.8 \%(12 / 64)$ and significantly associated with anti-MmmSC antibodies (OR: 3.6 (1.3-10.3; $\mathrm{p}<0.05)$. Herds from extensive management system $28.4 \%(19 / 67)$ have high prevalence than herds found in semi extensive management system $21.4 \%$ (6/28). Herd with history of contact with other herds $26.1 \%(24 / 92)$ has lower prevalence than herds with no history of contact with other herds $33.3 \%(1 / 3)$. Prevalence of CBPP in animals with history of new animal introduction $21.7 \%$ (10/42) was lower than herds with no history of new animal introduction $30.6 \%$ (15/49). Herds which had contact with other herds at watering point has $32.1 \%$ (9/28) high prevalence than herds contact with other herds both at watering and grazing point has $24.6 \%$ (15/61) (Table 2).

\section{Discussion}

The overall seroprevalence of MmmSC antibodies was estimated to be $8.6 \%$. Related result was reported by other investigators, $9.4 \%$ in Borena (Ahmed, 2004), 8.1\% by Mamo et al.(2018) and 9.7\% in south western Kenya (Schnier et al., 2006). The higher seroprevalence was previously reported from different regions of the country and outside of the country by other investigators, 39\% in Somali Regional State (Gedlu, 2004), 28.5\% in western Oromia (Daniel et al., 2016), 28\% in the Bodji district (Fikru, 2001), 25.3\% in Sidama Zone (Malicha et al., 2017) and 16\% in Kajiado district of Kenya (Matua-Alumira et al., 
2006) and on the other hand the lower seroprevalence also previously reported by others investigator, $4 \%$ in and around Adama (Kassaye and Molla, 2012), 6.14\% in Southern Ethiopia (Asmamaw, 2003), 1.4\% in Bale zone (Dereje and Shawul, 2017). The variation in prevalence of CBPP reported from different parts of Ethiopia and other countries might be due to differences in agro ecological systems, cattle management and production systems, population density, sample size and the types of tests used to determine the seroprevalence.

In this study, poor body condition was found significantly $(\mathrm{P}<0.05)$ associated with anti-MmmSC antibodies which agrees with finding of Atnafie et al. (2015) in Bishoftu abattoir which reported that poor body condition was significantly associated $(\mathrm{p}<0.05)$ with occurrence of CBPP. This might be due to the fact that animals with poor body conditions are more susceptible to the disease due to low immunity to resist disease.

Animals with history of disease was significantly $(\mathrm{P}<0.05)$ associated with anti- MmmSC antibodies. This might be due to the fact that previous diseased animals are carrier of $\mathrm{MmmSC}$ in lung sequestra. There was no any suggestion on previous studies that is parallel with this finding.

The statistical significant $(\mathrm{p}<0.05)$ association between the large herd sizes and sero-prevalence of anti- MmmSC antibodies was in agreement with study on bulls at finishing phase for export in East Shewa zone brought from Borena Pastoral Area of Southern Ethiopia in which there was significant association between prevalence of the CBPP antibodies as herd size increases reported (Alemayehu et al.,2015) The statistical significant $(\mathrm{p}<0.05)$ association between the large herd sizes and sero-prevalence of anti- MmmSC antibodies was in agreement with report of Alemayehu et al. (2015) which reported that the number of seropositive animals increases as the herd size increases $(\mathrm{p}<0.05)$ in both at herd and individual level, the highest CBPP prevalence was recorded in herd size $>1000$ and the difference was found statistically significant $(p<0.05)$ in Borena pastoral area of Southern Ethiopia. This might be related to the health management of large herd size and risks of an individual animal become infected with disease increases as herd size increase due to overcrowding of animals. 


\section{Conclusion}

The sero-prevalence of anti-MmmSC antibodies in the study areas at individual animal and herd level was relatively high as compared with different reports of the disease which indicated that the disease was prevalent in the study areas. Animals kept in these study areas are always at the risk of contracting CBPP because of their uncontrolled replacement of animals from outside origin and related management problem.

\section{Acknowledgements}

Authors would like to thank Gudeya Bila and Boneya Boshe districts for their technical support and also would like to thank Bedele regional veterinary laboratory for their material support.

\section{References}

Abera, Z., Mengistu, D., Batu, G. and Wakgari, M. 2016. Review on contagious bovine pleuropneumonia and its economic impacts. Acad. J. Anim. Dis., 5(1):1-15.

Adugna, T., A. 2017. Contagious bovine pleuropneumonia (CBPP): Literature review on distribution, sero-prevalence, and associated risk factors which plays major role in an economic loss of this sector. Austin J. Vet. Sci. Anim. Husb., 4(2).

Ahmed, I. 2004. Epidemiological study of contagious bovine pleuropneumonia in Borena pastoral areas using complement fixation test and competitive enzyme-linked immunosorbent assay. MSc thesis, Addis Ababa University, Debrezeit, Ethiopia.

Alemayehu, G., Leta, S. and Hailu, B. 2015. Sero-prevalence of contagious bovine pleuropneumonia (CBPP) in bulls originated from Borena pastoral area of Southern Ethiopia. Trop. Anim. Hlth. Prod., 47 (5): 983-987.

Asmamaw, M. 2003. Situation of CBPP in selected district of Southern Ethiopia. MSc thesis, Faculty of Veterinary Medicine, Addis Ababa University, Debrezeit, Ethiopia.

Atnafie, B., Goba, H., Sori, H., and Kasaye, S. 2015. Sero-prevalence of contagious bovine pleuropneumonia in abattoirs at Bishoftu and export-oriented feedlots around Adama. Global Veterinaria, 15 (3): 321-324.

BBLSRDO. 2017. Boneya Boshe woreda Livestock and Fishery Resource and Development office. Animal population annual report. Unpublished woreda report. 
CSA, (2017). Federal Democratic Republic of Ethiopia, central statistical agency. Agricultural sample survey. Report on Livestock and Livestock Characteristics (Private Peasant Holdings).

Daniel, G., Abdurahaman, M., Tuli, G. and Deresa, B. 2016. Contagious bovine pleuropneumonia: Seroprevalence and risk factors in Western Oromia, Ethiopia. Onderstepoort J. Vet. Res., 83 (1):1-5. doi: 10.4102/ojvr.v83i1.958.

DEFRA (Department for Environment, Food and Rural Affairs). 2001. Condition scoring of dairy cows. DEFRA Publications ONLINE: www.defra.gov.uk/corporate/ publications/pubfrm.htm, London, UK.

Dereje, L., and Shawul, W. 2017.A Sero-prevalence study of contagious bovine pleuropneumonia (CBPP) in Bale zone, Asella Regional Veterinary Laboratory, Asella, Ethiopia. Acad. J. Anim. Dis., 6 (3): 83-87.

Ebisa, T., Hirpa, H. and Aklilu, F. 2015. Study on seroprevalence and risk factors contagious bovine pleuropneumonia in Southern Nation and Nationality People of Ethiopia Regional State in Amaro special district. Sci. Tech. Arts Res.J., 4 (4):106.

Farmer, E. 2010. End market analysis of Ethiopian livestock and meat. A Desk Study Micro report, Published by The United States Agency for International Development (USAID).

Fikru, R. 2001. Herd prevalence of contagious bovine pleuropneumonia (CBPP), Bovine Tuberculosis and Dictyocaulosis in Bodji woreda, West Wollega. DVM Thesis, Faculty of Veterinary Medicine, Addis Ababa University, Debrezeit, Ethiopia.

GBLSRDO, 2017. Gudeya Bila woreda Livestock and Fishery Resource and Development office. Animal population annual report. Unpublished data.

Gedlu, M. 2004. Serological, clinical and participatory epidemiological survey of Contagious Bovine Pleuropneumonia in Somali Region, Ethiopia. MSC Thesis, Faculty of Veterinary Medicine, Addis Ababa University, Debrezeit, Ethiopia.

Joerg J. 2014. Developing an improved vaccine to control contagious bovine pleuropneumonia. Deutsche GesellschaftfürInternationaleZusammenarbeit (GIZ) GmbH, Bonn and Eschborn, Germany, in cooperation with Kenya Agricultural Research Institute (KARI), Kenya and Central Veterinary Laboratory Windhoek, Namibia.

John, C. 2016. Contagious bovine pleuropneumonia. In large animal clinical sciences, Western College of Veterinary Medicine, University of Saskatchewan. Merck and Co., Inc., Kenilworth, NJ, USA.

Kassaye, D., and Molla, W. 2012.Seroprevalence of contagious bovine pleuropneumonia at export quarantine centers in and around Adama, Ethiopia. Trop. Anim. Hlth. Prod., 45 (1):275-279. 
Lesnoff, M., Laval, G., Bonnet, P., Chalvet-Monfray, K., Lancelot, R. and Thiaucourt, F. 2004. A mathematical model of the effects of chronic carriers on the within-herd spread of contagious bovine pleuropneumonia in African mixed crop-livestock system. Prev. Vet. Med., 62 (2):101-117.

Malicha, G., Alemu, S., Aklilu, F. and Abraha, A. 2017. Study of seroprevalence and associated risk factors of contagious bovine pleuropneumonia in Sidama Zone, Southern Ethiopia. J. Vet. Sci. Tech., 8 (4):2.

Mamo, Y., Bitew, M., Teklemariam, T., Soma, M., Gebre, D., Abera, T., Benti, T. and Deneke, Y., 2018. Contagious bovine pleuropneumonia: seroprevalence and risk factors in Gimbo District, Southwest Ethiopia. Vet. Med. Internal. Volume 2018, Article ID 5729296, 7 pages. https://doi.org/10.1155/2018/5729296.

Matua-Alumira, R.W., Ng'ang'a, Z., Kiara, H., Matere, C., Mbithi, F., Mwirigi, M., Marobella-Raborogwe, C. and Sidiadie, S. 2006. The prevalence of CBPP in cattle under different production systems in Kajiado district, Kenya. In Proceedings of the $11^{\text {th }}$ International Symposium on Veterinary Epidemiology and Economics. Available at www.sciquest.org.nz.

Mersha, T. 2016. Sero-prevalence of contagious bovine pleuropneumonia and its potential risk factors in selected sites of Western Oromia, Ethiopia. Ethiop. Vet. J., 20 (2):31-41.

OIE. 2014.Office of International des Epizooties. Terrestrial Animal Health Code (Chapter 11.8.1). Paris, France.

Schnier, C., Mtui-Malamsha, N.J., Cleaveland, S., Kiara, H., Grace, D., McKeever, D.J. and Zadoks, R. 2006. Contagious bovine pleuropneumonia seroprevalence and associated risk factors in the Maasai ecosystem of south-western Kenya. In proceedings of the $11^{\text {th }}$ International Symposium on Veterinary Epidemiology and Economics.

Tambi, N.E., Maina, W.O. and Ndi, C. 2006. An estimation of the economic impact of CBPP in Africa. Rev.Sci. Tec., 25 (3): 999-1011.

Thrusfield, M. (2007). Veterinary Epidemiology. $2^{\text {nd }}$ edition, Blackwell Science Ltd. Edinburgh, UK, Pp: 178-197.

Tsedeke, K., and Endrias, G. 2011. Agro-ecologic mapping of livestock system in smallholder crop-livestock mixed farming of Wolayita and Dawuro districts, Southern Ethiopia. Livest. Res. Rural Dev., 23(3). 